\title{
DIGITAL FARMING: MAKING AGRICULTURE SUSTAINABLE, PROFITABLE AND ATTRACTIVE FOR INDIAN YOUTH
}

\section{SANJEEV KUMAR SABHARWAL ${ }^{1} \&$ Dr (Prof) SANJAY MOHAN JOHRI ${ }^{2}$}

${ }^{I}$ Research Scholar, Amity School of Communication, Amity University, Uttar Pradesh (AUUP), Lucknow Campus, Lucknow, Uttar Pradesh, India

${ }^{2}$ Director, Professor-Director, Amity School of Communication, Amity University, Uttar Pradesh (AUUP),

Lucknow, Campus, Lucknow, Uttar Pradesh, India

\begin{abstract}
The greatest need in the agricultural sector today is to communicate targeted and timely information to farmers based on their needs. This has necessitated the integration of digital technologies into agricultural extension programs for accurate, better, faster and cheaper transfer of technology (TOT) from lab to land. The objective of this research paper is to explore the role of Information and Communication Technology (ICT), Smartphone, Apps as a means of digital communication in knowledge sharing, market integration, targeted recommendations, getting financial help easily, helping stakeholders in making agriculture profitable sustainable enterprise thereby attracting farmers and especially the youth of India towards agriculture as a profession. Using Case Study, Survey and Interview methods this research paper examines the extent of penetration of agricultural apps and podcasts in the farmer community and its benefits, merits and demerits at the user's end. It also investigates the challenges involved in digital rural communication for development, training the farmers in the use of digital technology and their behaviour change. The findings are based on quantitative and qualitative analysis for which both secondary and primary data has been used.

KEYWORDS: Apps, Agricultural Extension, Digital Farming, ICT \& TOT
\end{abstract}

Received: Jun 10, 2020; Accepted: Jun 30, 2020; Published: Jul 16, 2020; Paper Id.: IJMPERDJUN2020357

\section{INTRODUCTION}

\subsection{Defining Digital Farming}

Immense advancement in the field of technology has transformed life of people in all aspects. However, the farming arena has not been benefited by these advancements significantly.

'Digital India' was launched by Prime of India Mr Minister Narendra Modi on $1^{\text {st }}$ July 2015, to craft a digital infrastructure which will help in the empowerment of rural sector. Motive behind this campaign was promotion of digital literacy. Thereby initiating Digital Farming or Digital Agriculture in India. Digital Farming can be put across as- ICT and big data ecosystems supporting the development and communication of timely and localised solutions or advisories on information and extension services to make farming sustainable and profitable. This would cover social, economic and environmental aspects related to agricultural development while delivering nutritious, safe and reasonably priced food for all. Rural connectivity will be major factor in providing low-cost data and access to information. It would empower rural youth to realise their full potential, farmers to increase their profitability by accessing equitable markets and rural businesses to offer value-added services. 
The key components to support the implementation of Digital Agriculture is Spatial (and Temporal) Data Infrastructure (SDI) and low-cost smart phones and tablets to support the bi-directional flow of data and information to rural consumers. Agriculture is a data-intense enterprise when one considers soil inconsistency, levels of nutrients and moisture and, rainfall unpredictability, and timing of sowing and harvesting, and market price instability. Therefore there is a need to help farmers manage production and market hazards through the application of spatial/temporal databases that are cloud-enabled and integrated through Application Programming Interfaces (APIs). This creates a loaded and active data ecosystem that enables advanced analysis to keep farmers informed on the best financial options to raise profitability and reduce the risk factor. These are the two major variables which Indian farmers would like to manage.

\subsection{Smartphone as the Key Intervention}

Smartphones play a major role in intervention. Since they are equipped with GPS which helps to track infestations on farms or damage caused by hail storm or inclement weather. Smartphones can provide technical support to farmers in getting claims of insurance. Mobile phones also enable farmers to join and be informed about structured markets. Standards of crops and vegetables can be verified with the help of sharing of photographs of the farm produce. Money payments can also be done using e-transfers.

Digital technology would help increase farm production by giving need based recommendations to farmers. This would inform farmers about suitable dates of sowing a particular crop, which variety to be sown, local weather information and proposed market rates of crops. Down-scaled observation of daily weather and advanced big data analysis will help putting across recommendations. This technology will help in telling farmers the most probable date for harvest, yields which could be obtained from a particular sown area, possibilities of pest attacks and outbreak of disease. Having known the farm related problems in advance, farmers can keep themselves prepared for measures to be taken for pest and disease control. Unmanned Aerial Vehicles (UAVs) have proved to be a boon in capturing multispectral images to assess damage, crop health, and yield of crops more accurately than satellites.

\subsection{Podcasts as a Means of TOT}

Podcasts are operationalised here as the medium of mass communication that includes video or audio files. They can be seen and heard on mobiles, computers, laptops and any other media gadgets. They are engaging devices of communication. These can be used as a means of TOT from lab to land by the extensionists. Videos on new technologies developed in labs, best practices in the field of agriculture can be prepared using the vernacular languages catering to the specific needs of farmers. Videos can be easily transferred to the target audience by means of WhatsApp and other apps.

\section{OBJECTIVE OF THE STUDY}

- To explore the role of Information and Communication Technology (ICT), Smartphone, Apps as a means of digital communication in knowledge sharing, market integration, targeted recommendations, getting financial help easily, helping stakeholders in making agriculture profitable sustainable enterprise thereby attracting farmers and especially the youth of India towards agriculture as a profession.

- To examine the extent of penetration of agricultural apps and podcasts in the farmer community and its benefits, merits and demerits.

- To investigate the challenges involved in digital rural communication for development, training the farmers in the use of digital technology and their behaviour change. 


\section{METHODOLOGY}

Below mentioned methodology, tools and techniques, study design and settings form the basis of this investigation:

- A mixed method approach of qualitative and quantitative data analysis was used by the researchers.

- Two Case Studies- Case studies on International Crops Research Institute for the Semi-Arid Tropics (ICRISAT), an International organization which conducts agricultural research for rural development and Digital Green, a development organization that helps marginal farmers by using the concept of partnership at the grassroots- level.

- Analysis of 15 apps related to agriculture and farming. These are- Grape Master, Grape Mundo, Shetkari Masik, Phule Krishi darshani App, Phule Jal, Phule Irrigation Scheduler (PIS), Hazera, E-NAM, Kisan Suvidha, Pusa Krishi, M Kisan, Farm O Pedia, Agri Market, Bhuvan Hailstorm, Crop Insurance

- $\quad$ The sample size for the survey- 75 farmers and Interview - 4 Scientists (Random Sampling).

- The schedule was filled by randomly selected 75 small and marginal onion and grapes cultivators of Niphad and Pimpalgaon Baswant villages of Nasik district of Maharashtra, India and 4 scientists of National Horticulture Research and Development Foundation (NHRDF), Niphad, district Nasik, Maharashtra India and Onion and Grapes Research Station, Pimpalgaon Baswant, district Nasik, Maharashtra, India were interviewed.

\subsection{Case Study 1- International Crops Research Institute for the Semi-Arid Tropics (ICRISAT)}

This case study describes the (International Crops Research Institute for the Semi-Arid Tropics)-ICRISAT's (Hyderabad) digital agriculture approach and specifically its experience integrating various digital tools and approaches in its programs, with a special focus on India. It provides insight into the impact of digital agriculture on ICRISAT's operations and works with partners and farmers.

ICRISAT is a research centre of Consultative Group for International Agricultural Research (CGIAR), it unites organizations which are involved in research in the field of agriculture for a food safe future. ICRISAT is intentionally and explicitly harnessing the power of digital technologies to conduct research more efficiently and deliver agricultural research outputs to farmers, extension officers, the government, and other agricultural value chain actors. While it has been almost ten years since ICRISAT first began integrating digital tools into its research programs, in 2014 digital agriculture became a critical component of the organization's mission to achieve scalable, sustainable, and equitable impact on the agriculture sector.

ICRISAT is creating a data ecosystem to drive the "Science of discovery to the science of delivery," the organization's tagline. Digital upgrades in data collection and analysis in the crop breeding pipeline, for example, are improving the accuracy and efficiency of the science of discovery. It is changing how scientists conduct research; shifting time spent on data collection to data analysis, and in the process unlocking opportunities to pursue new avenues of discovery. Digital tools are also accelerating the transfer of technologies developed in labs to farmers. Each digital tool is making targeted gains to advance research or improve service delivery. Together the tools and technologies are ushering in a new digital era for agriculture in which ICRISAT and its partners can deliver "better, faster, and cheaper" technologies and services to empower smallholder farmers.

Bhoochetana (2009-2012) was an integrated watershed management project developed by ICRISAT, the Karnataka Department of Agriculture, and local universities. It reached 4.75 million people. Farmers increased 
productivity by $20-60 \%$ and the agriculture sector grew by USD 353 million. Several digital tools supported these impacts.

- Digital Soil Health Maps: were created and posted online for 3.7 million hectares of land. These maps were a valuable resource that induced the Government of India to commit to mapping soil health for all farms by 2019 .

- Krishi Vani: provided free voice messages to 40,000 farmers using a "green sim." Weekly messages covered 16 categories like weather, markets, crops, and nutrition. Krishi Vani was created in partnership with Airtel and IFFCO Kisan Sanchar Ltd. and was piloted in 171 villages in Karnataka and Telangana.

- Krishi Gyan Sagar (KGS): a tablet-based extension system, provided personalized advisories to farmers based on data input. KGS expanded into Andhra Pradesh and Telangana after a pilot in Karnataka.

- The digital technologies highlighted below exemplify ICRISAT's current digital approach. While not allencompassing, the highlighted tools and technologies illustrate how ICRISAT is using digital tools to better serve farmers, forge impactful partnerships, and improve the efficiency of its work.

- Sowing App and the Intelligent Agricultural Systems Advisory Tool (ISAT): To provide farmers with timely and localised information about when to sow and what management practices to adopt. The Sowing app uses cloud-based predictive analytics tools on Microsoft Azure including Cortana artificial intelligence and machine learning to predict an optimal sowing period and other farm management practices. The Intelligent Agricultural Systems Advisory Tool (ISAT) integrates historical climate data, seasonal and short-term weather forecasts, soil information, and crop models to create decision trees with recommended actions for farmers. Both tools address these challenges by delivering SMS messages to farmers about when to sow and what management practices to adopt personalized to their village soil profile and weather forecast.

- iHub: The iHub is an incubator program at ICRISAT that that provides mentorship for agricultural technology start-ups to improve research programs and accelerate the science of delivery. The Digital Agriculture team launched the iHub in February 2017. The iHub is an innovation broker that creates partnerships between technology innovators and ICRISAT research programs. It connects entrepreneurs with mentors to help improve and iterate on innovations to meet needs across value chains and lead to social and economic impacts for farmers. There are currently twelve entrepreneurs in the iHub whose innovations create efficiencies in research, reduce costs, and improve farmer outcomes.

- Plantix: When crop health deteriorates, smallholders do not always know the reason or have an effective response, particularly when the cause is an uncommon pest or disease. Overtaxed extension systems are challenged to provide smallholders with the right information when they need it and farmers experience crop losses. In November 2016, ICRISAT and the government of Andhra Pradesh signed an MOU with PEAT to pilot Plantix at scale. Plantix is a free mobile crop advisory app developed by German start-up Progressive Environmental and Agricultural Technologies (PEAT). The app uses machine learning for automated image recognition that diagnoses over 240 plant diseases, pests, and nutrient deficiencies. An offline library details 400 total types of crop damage. Once Plantix identifies plant damage, it returns simple information on symptoms, triggers, controls, and preventative measures in English, Hindi, Telugu, or five other languages. The pilot targets government extension agents because of limitations in smartphone ownership and the opportunity to reach more total farmers through intermediaries. There are roughly 6,500 extension agents in Andhra Pradesh and each is 
responsible for a 5,000-hectare target area.

- Leasy Scan: The LeasyScan phenotyping platform automatically measures important characteristics related to leaf surface area and water stress for large quantities of plants. In the wake of a revolution in genomic tools driven by advances in technology, high throughput and precision phenotyping became a significant bottleneck for plant breeding (ICRISAT GEMS 2016). Before the LeasyScan, ICRISAT scientists cut and physically measured leaves to observe these characteristics. This process was slow and destroyed the plant, hindering comparison throughout an entire growth cycle. Hand measurement also introduced opportunities for inconsistencies and error within and across breeding programs at ICRISAT. ICRISAT collaborated with Phenospex in 2014 to adapt their scanner technology for high throughput phenotyping trials. The LeasyScan uses eight laser triangulation scanners and scales to create a database of 3D plant images and weights for up to 4,800 plants multiple times a day. The scanners are mounted on an irrigation boom that moves over experimental units without touching the plants, keeping them intact for comparison over time. This is quicker than other automated techniques that move plants through a stationary scanner at a much lower throughput (Vadez et al. 2015). Measurements from the LeasyScan are comparable to conventional measurements across multiple crops. Each plant is also bar-coded, so phenotyping teams can link qualitative observations of individual plants with database records to inform breeding decisions. Using the database, researchers extract simple, ready-to-use data about plant growth and transpiration to help select stress-tolerant germplasm for the development of improved varieties.

\subsection{Case Study 2- Digital Green}

Digital Green is a global development organization that empowers marginal farmers to lift themselves out of poverty by harnessing the collective and collaborative power of technology and grassroots-level collaborations.

Rikin Gandhi is the chief executive officer and co-founder of Digital Green. Digital Green received a US\$10 million grant in 2012 for the project with a target of reaching out to one million farmers (of which 500,000 would be unique adopters in India) in 10,000 villages, to be achieved by December 2018. Digital Green partners social and government organisations which are working with rural communities.

Digital green prepares videos on agriculture management and shares with stakeholders using digital media. These videos are prepared by villagers only in their language. This helps other farmers to identify themselves with the people shown on the videos and encourages them to use the new technology.

Two of the women farmers who have viewed and been helped by Digital Green's videos say about their experiences:

"After watching the video on Ghanjeevamrit (a manure mix), I became confident that I can also apply it on my land. The video explained that Ghanjeevamrit keeps the soil light and helps retain moisture. This helps in keeping the plants greener and healthier. The vegetables grown in this manure mix taste better."

"Initially, I was a bit apprehensive whether my field would adjust to this experiment. A few videos have helped me share the best agricultural practices and useful information with my neighbours. In these videos we see men and women like us explaining best practices related to farming in our own language" says Somia Devi, 46, of Nikaspur village, Samastipur District, Bihar, who owns a one kattha (22 kattha=1 acre) vegetable plot.

Pinky (30 years) resident of Nalanda district of Bihar, has been a part of a self-help group constituted by 
JEEVIKA, a partner organisation of Digital Green says "After having attended these video propagation, around 50 farmers of my village adopted the practice 'Rice Intensification'. She adds, 35 villagers now have kitchen gardens in their homes. This has helped them in increasing their farm output, ensuring food security and getting tasty and healthy food for their families."

\section{RESULTS AND DISCUSSIONS}

\subsection{Result and Analysis of the Survey}

- $100 \%$ of respondents possessed mobile phones out of these 60\% (Age group 20-40 years) were equipped with smartphones having internet connection.

- $100 \%$ of respondents who possessed smartphones had internet connection.

- $100 \%$ of respondents who possessed smartphones preferred watching videos (podcasts) on the development of new technologies on YouTube.

- Only 20\% of farmers in the age group 20-40 years used Apps for agricultural management.

- Among those who used various Apps $70 \%$ were grape cultivators and 30\% Onion Cultivators.

- $\quad 97 \%$ of farmers who possessed smartphones used WhatsApp.

- $\quad 95 \%$ of farmers who use WhatsApp share videos and information related to agriculture with farmer groups.

- $\quad 95 \%$ of farmers prefer getting information related to new technology and best practices through WhattsApp.

\subsection{Pros and Cons of Digital Farming}

\section{Pros}

Pros of Digital Farming are summarised under the four broad themes derived from the interview of the Agriculture Scientists. These themes are 1. Better Access to Information 2. Better access to extension services 3. Better market links and distribution networks 4 . Better access to finance. These are explained in the table given below-

Table 1: Summary of theme based Analysis of Interviews with the Agriculture Scientists

\begin{tabular}{|c|c|c|c|}
\hline $\begin{array}{l}\text { S.N } \\
\text { o. }\end{array}$ & Areas of Assistance & Benefits & Result/ Impact \\
\hline \multirow[t]{2}{*}{1} & \multirow[t]{2}{*}{$\begin{array}{l}\text { Better and easy access to } \\
\text { information }\end{array}$} & $\begin{array}{l}\text { Quick and accurate information on market, } \\
\text { higher prices, produce in greater demand }\end{array}$ & \multirow{7}{*}{$\begin{array}{l}\text { Higher-income } \\
\text { for the farmers having } \\
\text { smaller landholdings. } \\
\text { - The lower } \\
\text { transaction, logistical and } \\
\text { distribution costs for input } \\
\text { suppliers }\end{array}$} \\
\hline & & $\begin{array}{l}\text { Personalised climate and plant disease } \\
\text { information for better risk and disaster } \\
\text { management. }\end{array}$ & \\
\hline \multirow[t]{2}{*}{2.} & \multirow[t]{2}{*}{$\begin{array}{l}\text { Better and easy access to } \\
\text { extension services }\end{array}$} & $\begin{array}{l}\text { Knowledge of best practices in agriculture } \\
\text { for higher yield of the crops. }\end{array}$ & \\
\hline & & Ease in TOT and extension services. & \\
\hline \multirow[t]{2}{*}{3.} & \multirow[t]{2}{*}{$\begin{array}{l}\text { Better and easy market and } \\
\text { distribution networks. }\end{array}$} & $\begin{array}{l}\text { Direct links between farmers, buyers and } \\
\text { suppliers will reduce the scope of } \\
\text { exploitation by middlemen and introduce } \\
\text { more efficient distribution chains. }\end{array}$ & \\
\hline & & $\begin{array}{l}\text { Better recording, accounting and } \\
\text { traceability for increased efficiency and } \\
\text { predictability, reduced administrative costs } \\
\text { and reduced fraud. }\end{array}$ & \\
\hline 4. & Better and easy access to finance & Ease in getting- credit, insurance and & \\
\hline
\end{tabular}




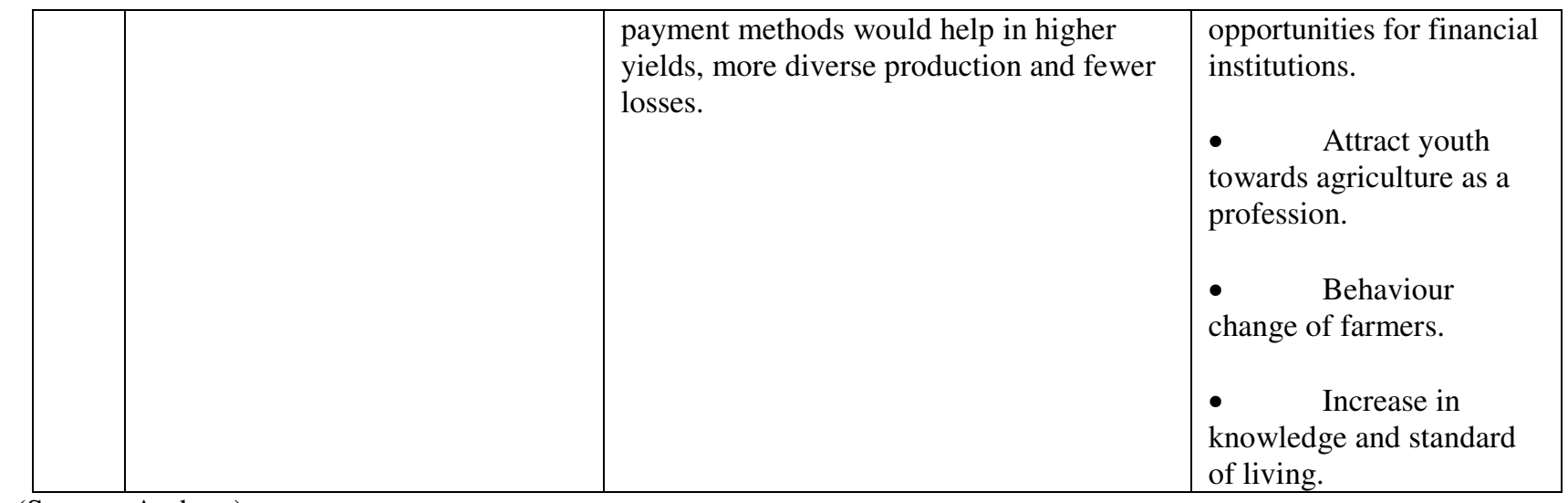

(Source- Authors)

\section{Cons-}

The Scientists enumerated that-

- A proper training program, uninterrupted electric supply, availability of smartphones, tablets and computers to almost every farmer can be a big challenge.

- There is a lack of digital literacy in India.

- Lack of smartphone availability - Most of the farmers do not have access to an affordable smartphone therefore they are not able to avail all the facilities related to digital farming.

- The linguistic diversity of India makes the integration of language with technology difficult.

- Supply of continuous electricity in most of the Indian villages is a challenge, digitalising such villages is difficult.

- Training to farmers on digital farming is difficult.

- Attitude of most of the people involved in agricultural activities like farmers, extension workers is not pro-digital.

- All Indian languages are not included in Apps related to Agriculture.

- According to users, some time information related to weather forecast and Mandi price is not accurate therefore they cannot rely on it.

- Some of the Apps are not updated regularly.

- All districts and Mandis are not included in the Apps.

\subsection{Analysis of 15 Apps}

Analysis of 15 apps related to agriculture is given in the Table-2 which is presented as Annexure1

It reflects that very few people are using these apps. The reviews of the users mention that the apps are not updated regularly, sometimes weather information is not correct, people demand that the apps should be in all vernacular languages to cater to larger group of people. However, many users speak high about the apps as they help in agriculture management in an efficient manner, keep farmers updated about the weather conditions, latest rates, marketing, insurance claims, irrigation, sowing, harvesting techniques and TOT. These apps are considered to be the best means to make agriculture sector sustainable, profitable and attract Indian youth towards farming.

\section{CONCLUSIONS, SUGGESTIONS AND RECOMMENDATIONS}

Central and State Governments, Non Government Organisations, Development Agencies, Agricultural Universities, Foundations can take ideas and clues from the following suggestions and recommendations to digitise agriculture and make it sustainable, profitable and attractive for Indian youth. 
- All Extension staff of Agricultural universities and Agriculture departments to be made digital and tech-savvy who in turn can train farmers.

- Maximum number of farmers to be provided with smartphones.

- There is a need for uninterrupted power supply in villages.

- Apps to be developed in major Indian languages, updated regularly and an accurate information to be provided through these apps to gain confidence of the users.

- Maximum districts and Mandis to be included in the apps.

- The youth of India to be informed about the Government schemes about Digital Farming.

- Training camps for youth to enumerate profitable digital agriculture.

- Farmers to be trained in the use of Apps related to agricultural management and how to utilise the information for their benefits.

- Agricultural Universities should develop podcasts related to new technologies developed in labs, in vernacular languages and share it through WhatsApp group of farmers.

- Annual reports of agricultural Universities should mention the number of podcasts uploaded on the University websites and shared with farmers through various means.

\section{REFERENCES}

1. Bergvinson, David. (2017). Digital Agriculture Empowers Farmers. Business Today. https://www.businesstoday.in/magazine/features/digital-agriculture-empowers-farmers/story/242966.html

2. Retrieved from. bitstream/handle/10947/4488/Open\%20Access\%20Data\%20Management\%20Policy.pdf? sequence $=1$

3. Bossuet, J. (2017). Savvy sowing for Indian monsoon dependent farmers. Thomas Reuters Foundation.

4. CGIAR. (2013). CGIAR Open Access and Data Management Policy. https://cgspace.cgiar.org/

5. Das, S. (2017). Indian Sates Go Big on Blockchain for Land Registry, Pensions. CCN. https://www.ccn.com/indian-stateslaunch-blockchain-pilot-landregistry-records/

6. Food and Agriculture Organization of the United Nations (FAO). (2017). India and FAO: Promoting food security and sustainable development in India and around the world. FAO. Rome, Italy. http://www.fao.org/3/au079e/AUO79E.pdf

7. GSMA. (2015). Bridging the gender gap: Mobile access and usage in low- and middle-income countries.

8. GSMA. (2018). The Mobile Economy 2018. GSMA. London, UK.

9. Government of India. (2017). Agricultural Statistics at a Glance 2016. Government of India. New Delhi, India. http://eands.dacnet.nic.in/PDF/Glance-2016.pdf

10. Retrieved from. http://businesseconomics.in/pros-and-cons-digital-india

11. Retrieved from. https://news.trust.org/item/20170825154606- $t 392 u$ /

12. Retrieved from. https://www.gsma.com/mobileeconomy/wp-content/uploads/2018/02/The-Mobile-Economy-Global-2018.pdf

\section{APPENDIX 1}

\section{Survey Schedule}

\begin{tabular}{|c|c|c|c|}
\hline S.No. & Question & \multicolumn{2}{|c|}{ Response } \\
\hline 1 & What is your Age? & & \\
\hline 2 & Which farming are you engaged in Onion or Grapes? & & \\
\hline 3 & Do you have Mobile Phone? & Yes & No \\
\hline 4 & Is your Mobile a Smart Phone? & Yes & No \\
\hline 5 & Do you have internet connection in your Smart Phone? & Yes & No \\
\hline 6 & $\begin{array}{l}\text { Do you prefer watching videos (podcasts) on the development of new } \\
\text { technologies on YouTube? }\end{array}$ & Yes & No \\
\hline 7 & Do you use Apps related to agricultural management? & Yes & No \\
\hline 8 & Do you use WhatsApp? & Yes & No \\
\hline 9 & Do you share videos and information related to agriculture with farmer groups? & Yes & No \\
\hline 10 & Do you prefer getting information related to new technology and best practices & Yes & No \\
\hline
\end{tabular}




\section{APPENDIX 2}

\section{Questionnaire for Interview}

\begin{tabular}{|l|l|}
\hline S.No. & \multicolumn{1}{c|}{ Question } \\
\hline 1 & $\begin{array}{l}\text { What according to you are the benefits of digital farming to farmers in terms of the following? } \\
\text { (a) Access to information }\end{array}$ \\
& $\begin{array}{ll}\text { (b) } \quad \text { Access to extension services } \\
\text { (c) } \quad \text { Market and distribution services } \\
\text { (d) } \quad \text { Access to finance }\end{array}$ \\
\hline 2 & What according to you are the challenges related to digital farming? \\
\hline 3 & Do farmers need training on digital agriculture? \\
\hline 4 & What is the attitude of people involved in agricultural activities towards digital agriculture? \\
\hline 5 & What role do the Apps play in the promotion of digital agriculture? \\
\hline
\end{tabular}

\begin{tabular}{|c|c|c|c|c|c|c|c|c|}
\hline $\begin{array}{l}\mathbf{S} \\
\mathbf{N} \\
\mathbf{0}\end{array}$ & $\begin{array}{l}\text { Name } \\
\text { of the } \\
\text { App }\end{array}$ & Purpose & Language & Downloads & $\begin{array}{l}\text { Total number } \\
\text { of users who } \\
\text { rated }\end{array}$ & $\begin{array}{l}\text { Rating } \\
\text { Star }\end{array}$ & $\begin{array}{l}5 \text { Star } \\
\text { Rating }\end{array}$ & $\begin{array}{l}\text { Percenta } \\
\text { ge of } 5 \\
\text { star } \\
\text { rating }\end{array}$ \\
\hline 1 & $\begin{array}{l}\text { Grape } \\
\text { Master }\end{array}$ & $\begin{array}{l}\text { Help grape farmers in crop, irrigation, soil, } \\
\text { fertilizer, pest management, good yield, } \\
\text { less input cost, more income, marketing of } \\
\text { the produce. }\end{array}$ & $\begin{array}{l}\text { English, } \\
\text { Marathi }\end{array}$ & $10,000+$ & 1024 & 4.7 & 821 & 80.18 \\
\hline 2 & $\begin{array}{l}\text { Grape } \\
\text { Mundo }\end{array}$ & $\begin{array}{l}\text { Transforming traditional grape farming } \\
\text { to smart Grape farming. }\end{array}$ & $\begin{array}{l}\text { English, } \\
\text { Marathi, } \\
\text { Kannad }\end{array}$ & $5000+$ & 142 & 4.5 & 99 & 69.72 \\
\hline 3 & $\begin{array}{l}\text { Shetkari } \\
\text { Masik }\end{array}$ & $\begin{array}{l}\text { "Shetkari Masik" is one of the most } \\
\text { popular monthly magazines in the } \\
\text { Agriculture sector, under publication since } \\
\text { 1965. It is published by Department of } \\
\text { Agriculture, Maharashtra. } \\
\text { The Android app for Shetkari magazine } \\
\text { has a very simple interface and requires } \\
\text { mobile internet or Wi-Fi connectivity to } \\
\text { register and download the issues. Once } \\
\text { downloaded, the magazine can be read } \\
\text { without internet connectivity. }\end{array}$ & Marathi & $1,00,000+$ & 2534 & 4.2 & 1550 & 61.17 \\
\hline 4 & $\begin{array}{l}\text { Phule } \\
\text { Krishi } \\
\text { darshani } \\
\text { App }\end{array}$ & $\begin{array}{l}\text { Provide information about crops, } \\
\text { instruments, modern technology to farmers } \\
\text { for additional growth. }\end{array}$ & Marathi & $10,000+$ & 162 & 3 & 53 & 32.72 \\
\hline 5 & $\begin{array}{l}\text { Phule } \\
\text { jal }\end{array}$ & $\begin{array}{l}\text { Irrigation water requirement advisory } \\
\text { (Evapotranspiration). }\end{array}$ & English & $1000+$ & 37 & 4.9 & 34 & 91.89 \\
\hline 6 & $\begin{array}{l}\text { Phule } \\
\text { Irrigatio } \\
\mathrm{n} \\
\text { Schedul } \\
\text { er (PIS) }\end{array}$ & Irrigation Management & $\begin{array}{l}\text { English, } \\
\text { Marathi }\end{array}$ & $1000+$ & 22 & 4.6 & 19 & 86.36 \\
\hline 7 & Hazera & Onion Diseases & English & $5000+$ & 51 & 4.5 & 34 & 66.67 \\
\hline 8 & e NAM & $\begin{array}{l}\text { An electronic trading platform that } \\
\text { connects different mandis/ markets for } \\
\text { farm produce (National Agriculture } \\
\text { Market- NAM Pan India electronic } \\
\text { trading Portal). Basically for Farmers, } \\
\text { Traders, Commission Agents, } \\
\text { Processors, Exporters, Mandi } \\
\text { functionaries. }\end{array}$ & $\begin{array}{l}9 \\
\text { languages } \\
\text { including } \\
\text { English, } \\
\text { Hindi, } \\
\text { Marathi, } \\
\text { Gujarati, } \\
\text { Bengali } \\
\text { Oria and } \\
\text { Punjabi } \\
\end{array}$ & $50,000+$ & 404 & 3.9 & 236 & 58.42 \\
\hline 9 & $\begin{array}{l}\text { Kisan } \\
\text { Suvidha }\end{array}$ & $\begin{array}{l}\text { Information on weather of current day } \\
\text { and next } 5 \text { days, dealers, market prices, } \\
\text { agro advisories, plant protection, call to } \\
\text { KCC, Soil health card, cold storage and } \\
\text { godowns. Unique features like extreme } \\
\text { weather alerts and market prices of } \\
\text { commodity in nearest area and the } \\
\text { maximum price in state as well as India } \\
\text { have been added to empower farmers in } \\
\text { the best possible manner. }\end{array}$ & $\begin{array}{l}8 \\
\text { languages } \\
\text { English, } \\
\text { Hindi, } \\
\text { Marathi, } \\
\text { Gujarati, } \\
\text { Bengali } \\
\text { oria and } \\
\text { Punjabi }\end{array}$ & $5,00,000$ & 5,565 & 4.2 & 3,372 & 60.59 \\
\hline
\end{tabular}




\begin{tabular}{|c|c|c|c|c|c|c|c|c|}
\hline $\begin{array}{l}1 \\
0\end{array}$ & $\begin{array}{l}\text { Pusa } \\
\text { Krishi }\end{array}$ & $\begin{array}{l}\text { It promotes Agribusiness Ventures } \\
\text { through technology development and } \\
\text { commercialization for everyone from a } \\
\text { corporate to an individual farmer. }\end{array}$ & English & $3,41,017$ & $\begin{array}{l}\text { This app is not a } \\
\text { store. It can be d } \\
\text { www.socialapph }\end{array}$ & $\begin{array}{l}\text { ble on } \\
\text { oadec }\end{array}$ & & NA \\
\hline $\begin{array}{l}1 \\
1\end{array}$ & M Kisan & $\begin{array}{l}\text { It enables farmers and all other } \\
\text { stakeholders to obtain advisories and } \\
\text { information being sent by experts and } \\
\text { government officials at different levels } \\
\text { through mkisan portal without } \\
\text { registering on the portal. Features- Pull } \\
\text { SMS, IVRS-Interactive Voice Response } \\
\text { System, Push SMS, KCC, USSD. }\end{array}$ & English & 10,000 & 137 & 4.1 & 84 & 61.31 \\
\hline $\begin{array}{l}1 \\
2\end{array}$ & $\begin{array}{l}\text { Farm O } \\
\text { Pedia }\end{array}$ & $\begin{array}{l}\text { It is a multilingual Android application } \\
\text { targeted for rural Gujarat. The app is useful for } \\
\text { farmers or anyone related to agriculture. The } \\
\text { main functionalities of the app are: 1.Get } \\
\text { suitable crops as per soil and season } \\
\text { 2.Get crop wise information } \\
\text { 3.Check weather in your area } \\
\text { 4.Manage your cattle }\end{array}$ & $\begin{array}{l}\text { English } \\
\text { and } \\
\text { Gujarati }\end{array}$ & 2,967 & $\begin{array}{l}\text { This app is not } \\
\text { available on the } \\
\text { play store. It } \\
\text { can be } \\
\text { downloaded } \\
\text { from } \\
\text { https://apps.mg } \\
\text { ov.gov.in/index } \\
\text { jsp }\end{array}$ & 3 & NA & NA \\
\hline $\begin{array}{l}1 \\
3\end{array}$ & $\begin{array}{l}\text { Agri } \\
\text { Market }\end{array}$ & $\begin{array}{l}\text { It can be used to get the market price of } \\
\text { crops in the markets within } 50 \mathrm{~km} \text { of the } \\
\text { device's location. This app } \\
\text { automatically captures the location of } \\
\text { person using mobile GPS and fetches the } \\
\text { market price of crops in those markets } \\
\text { which falls within the range of } 50 \mathrm{~km} \text {. } \\
\text { There is another option to get price of } \\
\text { any market and any crop in case person } \\
\text { does not want to use GPS location. }\end{array}$ & $\begin{array}{l}\text { English, } \\
\text { Hindi and } \\
5 \text { other } \\
\text { languages }\end{array}$ & $1000+$ & 5 & 4.5 & 3 & 60.00 \\
\hline $\begin{array}{l}1 \\
4\end{array}$ & $\begin{array}{l}\text { Bhuvan } \\
\text { Hailstor } \\
\text { m }\end{array}$ & $\begin{array}{l}\text { Developed by ISRO. It captures crop } \\
\text { loss happened due to hailstorm. } \\
\text { Agriculture Officer will go to the field } \\
\text { with mobile or tablet loaded with this } \\
\text { mobile app. This mobile app is able to } \\
\text { capture following parameters: } \\
\text { 1.Photograph of field with latitude and } \\
\text { longitude. } \\
\text { 2.Name of Crop } \\
\text { 3.Date of sowing } \\
\text { 4.Date of likely harvesting } \\
\text { 5.Source of irrigation. } \\
\text { This captured data will automatically be } \\
\text { plotted to Bhuvan Portal and analysis } \\
\text { can be done easily. The app is used by } \\
\text { State agriculture officials and the data } \\
\text { captured help the Union Agriculture } \\
\text { Ministry in having very fast assessment } \\
\text { of damage to crops because of } \\
\text { hailstorm. To fasten payment of crop } \\
\text { insurance claims to farmers }\end{array}$ & English & NA & $\begin{array}{l}\text { This app is } \\
\text { available at } \\
\text { https://bhuvan- } \\
\text { appl.nrsc.gov.i } \\
\text { n/hailstorm/ }\end{array}$ & NA & NA & NA \\
\hline $\begin{array}{l}1 \\
5\end{array}$ & $\begin{array}{l}\text { Crop } \\
\text { Insuranc } \\
\mathrm{e}\end{array}$ & $\begin{array}{l}\text { App can be used to calculate the } \\
\text { Insurance Premium for notified crops } \\
\text { based on area, coverage amount and } \\
\text { loan amount in case of loaned farmer. It } \\
\text { can also be used to get details of normal } \\
\text { sum insured, extended sum insured, } \\
\text { premium details and subsidy information } \\
\text { of any notified crop in any notified area. }\end{array}$ & $\begin{array}{l}\text { English, } \\
\text { Hindi and } \\
\text { Marathi }\end{array}$ & $50,000+$ & NA & 3 & 22 & NA \\
\hline
\end{tabular}

